\title{
10 Social Enterprise in Russia
}

Developing Social

Entrepreneurship Models

in the Russian Legal and

Socio-economic Context

Yury Blagov and Yulia Aray

\section{Introduction}

The purpose of this chapter is to identify the social-entrepreneurship models and the main drivers and features of their development in the legal and socio-economic context of the Russian Federation. Due to the peculiarities of the transition period, the country underwent from the early1990s onwards, the way in which social entrepreneurship has been and is still being implemented in Russia is complex and rather unique but has not been investigated specifically as yet.

According to an early approach by Kerlin, social enterprises in EastCentral Europe are located between the market, international aid and civil society (Kerlin 2009). Nevertheless, such a pattern is not relevant in the Russian Federation, where the role of international aid is steadily shrinking and civil-society institutions are just emerging. According to the typology subsequently developed by Kerlin (Kerlin 2013, 2017), social enterprise (SE) in Russia appears to be very close to the so-called "enmeshed-focused" model, with state subsidies for implementation, and few and little diversified kinds of social enterprise. This model should theoretically be connected with an "innovative-driven" economy (ibid.), but the modern Russian economy is rather "efficiency-driven", or even "factor-driven", taking into consideration the importance of oil/gasextracting industries in the GDP (GEM 2017).

Contemporary Russian scholars began to demonstrate interest in socialentrepreneurship issues less than fifteen years ago. Early publications in this field appeared in 2008-2010 (Batalina et al. 2008; Blagov and Aray 2010; Zelenova 2010) and were mostly descriptive; they focused not only on presenting foreign theoretical approaches and practical experiences but also on analysing the nature of social entrepreneurship in Russia. The analyses of social entrepreneurship happened to be quite different depending on the authors' background and affiliations, and they covered a broad spectrum, from a "new kind of charity" and "changing social policy" to "particular business activity". Since 2011-2012, publications 
have tended to focus on case mapping and analysis of exemplary initiatives, as well as on attempts to create empirically tested typologies and classifications (Moskovskaya 2011; Aray and Burmistrova 2014; Vetrova 2015; Moskovskaya and Soboleva 2016; Vayner and Bolshakova 2015; Vayner et al. 2016, 2017). Following the academic community's request, some works combine empirical evidence with teaching materials (Zvereva 2015; Blagov 2017). Nevertheless, empirical publications are still limited to qualitative studies, while quantitative analyses continue to be hindered by the underdevelopment and ambiguity of the phenomenon itself.

This chapter consists of four parts. In Section 1, the historical premises of social-entrepreneurship development in Russia are presented and analysed. In Section 2, the role of the state and large corporations as the main drivers of social-entrepreneurship development in Russia is explored. The purpose of Section 3 is to describe the typology of socialentrepreneurship models in the Russian Federation. The conclusion summarises the chapter and presents key findings.

\section{Historical Premises of Social-Entrepreneurship Development in Russia}

A rapid development of social entrepreneurship has only been observed in Russia during the last decade, but some premises of entrepreneurial approaches to social problem-solving are deeply rooted in the past. On the one hand, a tradition of institutional charity was implanted in Kievan Rus' $^{11}$ as soon as in the 10th century. On the other hand, cooperative associations, as a historical feature of civil society, started to appear in Russia from the end of the 19th century onwards. In spite of dramatic socio-economic shifts in the 20th century, such embedded peculiarities have created an important path-dependency effect. Historically, this path-dependency can be traced through three major periods: the period before the October 1917 revolution (pre-Soviet period); the period of communist-ideology dominance, until the Soviet Union's collapse in 1991 (Soviet period); and the period of market-economy formation, from 1992 to the present (modern period).

\subsection{The Pre-Soviet Period (Until October 1917)}

After the adoption of Christianity in Kievan Rus', in 988, churches and monasteries became centres that provided social help to the most vulnerable segments of society. Moreover, rules that made it obligatory for beggars to live in monasteries were introduced by the "Code of Law" (Sudebnik) of Tsar Ivan IV ("The Terrible") in 1550. Later, in the Russian Empire, a lot of special orders were issued by the state to set up and financially support orphanages as well as special medical institutions for the disabled and people with mental disorders. Considering the subordinate 
role of the Orthodox Church as a particular "governmental office" and the late industrialisation (the Russian Empire's industrialisation took place in the 19th century, which determined a relatively low level of entrepreneurial activity in general), it was the state (or/and the imperial family) that took the main responsibility for charity development and for creating the predecessors of social enterprises, such as "workhouses" and "houses of diligence" (see later). Private benefactors-rich merchants and industrialists-were involved not only in taking paternalistic care of their employees' living conditions but also in patronising arts, theatres, library funds, scientific research and other activities not always directly related to the struggle against poverty. This patronage was usually treated by benefactors as pure charity, guided by Christian morality.

The system of state-funded workhouses was initially created by Russian Empress Catherine II "the Great" in 1775, with the purpose of "forcing beggars to work". Later, these institutions were transformed into houses of diligence, that is, donation-based organisations of work assistance and social adaptation. The founder of the first "true" house of diligence was a priest, Saint John of Kronstadt, who started this project in 1881 with charity funds, including donations from the imperial family. In 1896, the initiative provided work to 21,876 people in need (Gatilova 2008). In 1895, Russian Empress Alexandra Fedorovna created a particular office-the "Guardianship for workhouses and houses of diligence"-to unify the rules governing these initiatives and share best practices. By the beginning of the 20th century, there were about 130 large houses of diligence throughout the Russian Empire (KazakovaApkarimova 2010). Despite the fact that houses of diligence were unprofitable and could not survive without continuous donations, they became prototypes of modern social enterprises, carrying out their activities based on social and economic adaptation and work integration of particular groups of people.

As far as cooperatives are concerned, in pre-Soviet Russia, for a long time (since the 13th or 14th century), there have been different forms of socio-economic associations of people aiming to achieve specific social and economic purposes, such as artels and peasants' communities. However, the creation of the first "modern" cooperative establishment only dates back to 1885: it was a mutual-aid fund for peasants, founded by the Louchinin brothers, from the Kostroma province, under the form of a savings and loan association. By 1916, there were more than 14,000 such associations, with a total number of shareholders of around 8 million people, and it was the leading form of cooperative in Russia, which was mostly an agrarian country. By the beginning of the 20th century, Russia had become the global leader in terms of the number of cooperatives and membership: by the end of 1916, there were about 50,000 cooperatives in the country, involving more than 14 million people (Elyutin 2003). 


\section{Blagov \& Aray}

\subsection{The Soviet Period (From October 1917 to 1991)}

The October revolution of 1917 constituted a turning point in Russian history, which transformed the very approach to social problem-solving.

First, the tradition of charity was completely reoriented to state support and control. All the resources of private and public charity foundations were nationalised, and the responsibility for social obligations was fully imposed on the socialist "state of workers and peasants". All houses of diligence and similar "quasi-entrepreneurial" entities were gradually closed, in line with private-property dissolution. However, the existence of a multitude of critical social problems in society, such as child neglect, forced the state to create new or transform the traditional organised forms of mercy and charity. In general, almost all attempts at renewal of charity initiatives were reduced to money collection for different needs through membership fees in respective organisations rather than through true donations. This concerned not only the newly created bodies, such as the "Child Fund named after V.I. Lenin" (Detskiy Fond imeni Vladimira Il'icha Lenina), but also the Red Cross and Red Crescent Societies, both operated in the Soviet Union on "obligatory donations" from all able-bodied citizens and on state subsidies (Utkin 2014).

Secondly, the so-called "socialist enterprises" were de jure and de facto appointed to take care of the local communities in the territories where they operated. Such evolution was typical in particular of large enterprises in the extracting and heavy industries, which officially had to finance the social infrastructure of the cities and regions where they were present from their own resources, in addition to the local and federal state budgets expenditures. This obligatory support had nothing in common with voluntary charity donations. Not being, by definition, business entities, these "socialist enterprises" did not fully act as social entrepreneurs, but they had to plan and calculate their social expenditures.

Thirdly, the field of cooperative associations was gradually reduced to include only consumer cooperatives and folk crafts artels. These cooperatives were almost completely organised by and for the agricultural population, with the aim of retailing consumer goods; procuring mushrooms, berries and medicinal herbs; and producing foodstuff from local raw materials. In 1990, these entities, with more than 30 million membervillagers, served about $40 \%$ of Soviet citizens (Elyutin 2003). In a general sense, they can be considered as constituting a form of social entrepreneurship, due to their real positive impact on the low living standards of peasants. The collective farms, as the main organisational form of Soviet agriculture, were officially proclaimed to constitute the "top of the cooperative pyramid", but in practice, they had nothing in common with entrepreneurial activity as such. 


\subsection{The Modern Period (From 1992 Onwards)}

Market-economy formation in Russia after the Soviet Union's collapse happened gradually, and old traditions of charity and mutual aid, as well as entrepreneurship development in the social sphere, were revived step by step. In fact, some pre-Soviet approaches to solving social problems started a "second life". For example, the house of diligence "Noah", in the Moscow region, was created by the Orthodox Church for people who, for some reasons, had become homeless but were ready to work. Today, there are about 1,050 people living in this house of diligence, $45 \%$ of whom are able-bodied men, and $55 \%$ are disabled persons, women with children and elderly people. All of them are working as non-qualified staff. Sixteen branches of the house of diligence "Noah" have been created in Moscow and in the Moscow and Vladimir areas. ${ }^{2}$

In general, the old traditions are re-appearing with the re-introduction of the state and corporations as leading actors.

State social programmes are maintained but their budget is shrinking, so corporate philanthropy programmes are being actively developed in the Russian Federation (Blagov and Petrova-Savchenko 2012). The share of corporate giving in comparison to private giving remains very high in Russia (corporate giving currently represents about $90 \%$ of total giving). Such a situation seems to be part of an implicit social contract established in the mid-1990s between the state and big businesses, after the controversial process of privatisation in favour of the new rich. In accordance with this implicit contract, the Russian state and Russian society view corporate giving as "redemptive" financial support complementing-or even as a substitution for-the state's social expenditures. In turn, this approach provides businesses with a "license to operate".

On the other hand, cooperative private initiatives aimed at the enhancement of living and working conditions have just started to emerge. The Civil Code of the Russian Federation stipulates that there are two types of cooperatives: industrial (commercial) cooperatives and consumer (nonprofit) cooperatives. The current revival of cooperatives is mainly linked to consumer cooperatives in agriculture. It is revealing that the 2017 edition of the "Social Entrepreneurship in Russia" catalogue ${ }^{3}$ contains only one example of a cooperative, namely the LavkaLavka cooperative, which has been created by farmers, consumers, stores, restaurants, hotels and foodstuff suppliers with the purpose of satisfying consumer needs through environmentally friendly products (Vayner et al. 2017).

\section{Major Drivers of Social-Entrepreneurship Development in Russia}

The peculiarities of social entrepreneurship in Russia are to a large extent determined by the fact that its major drivers are the state and 


\section{Blagov \& Aray}

large corporations, which consider social entrepreneurship through the prism of fulfilling their own tasks. This means that socialentrepreneurship development mainly occurs through the stimulation of such activity "from the top", rather than being a natural process of "bottom-up" development of initiatives aiming to make up for government and market failure. Other drivers of social-entrepreneurship development, such as international foundations (Ashoka, Reach for Change, etc.), civil-society initiatives (Russian Micro-Financial Centre, among others) and universities (St. Petersburg State University, National Research University-Higher School of Economics, etc.) play a minor role and try to connect and correlate their activities with the efforts of the state and corporations.

\subsection{The State}

The state is interested in developing social entrepreneurship as an alternative tool for solving social problems. It is important to emphasise that social entrepreneurship is usually seen in the Russian Federation as a special case of entrepreneurial activity of small and medium enterprises (SMEs). Since 2012, the Ministry for Economic Development of the Russian Federation has managed the annual programmes offering financial and institutional support to SMEs, including "social entrepreneurship", defined as SMEs' socially oriented activities. In accordance with these programmes, social entrepreneurs are supported through regional governments, mainly represented by the so-called "Centres of Innovation in the Social Sphere" (CISS). ${ }^{4}$ On June 2, 2016, the federal government introduced the Strategy for the Development of Small and Medium Business in the Russian Federation until 2030, with a precise "roadmap" for social-entrepreneurship improvements. ${ }^{5}$

Finally, on July 26, 2019, the federal government approved the "Amendments to the Law on the Development of Small and Medium Enterprises", which include legal regulations directly connected to social entrepreneurship. ${ }^{6}$ These amendments define social entrepreneurship as "an entrepreneurial activity aimed at achieving socially useful goals, contributing to the solution of social problems of citizens and society" and social enterprise as "a subject of small or medium-sized businesses engaged in activities in the field of social entrepreneurship". They also clearly distinguish social enterprises from other kinds of SMEs in the social sphere by providing a list of four formal criteria, one of which at least has to be met for an enterprise to quality as a social enterprise:

1. A social enterprise provides employment to people belonging to any of the categories defined as vulnerable. The average number of persons belonging to any of these categories must represent at least $50 \%$ of the SME's employees, and the labour costs of persons belonging to 
any of these categories must represent at least $25 \%$ of the enterprise's total labour costs.

2. A social enterprise ensures the sale of goods or services by citizens belonging to any of the categories defined as vulnerable. The share of income generated by such activities must represent at least $50 \%$ of the total income of the SME, and the share of net profit linked to these activities should account for at least $50 \%$ of the total net profit reported by the enterprise.

3. A social enterprise carries out the production of goods or the provision of services intended for citizens belonging to any of the categories defined as vulnerable, in order to create for these citizens conditions that will enable them to overcome or make up for the limitations they face in their activities, as well as opportunities for these citizens to participate in society on an equal footing with other citizens. The share of income from such activity should represent at least $50 \%$ of the total income of the SME, and the share of net profit linked to these activities should account for at least $50 \%$ of the total net profit reported by the enterprise.

4. A social enterprise carries out activities aimed at achieving socially useful goals and contributing to the solution of social problems. The share of income generated by such activities should represent at least $50 \%$ of the total revenue of the SME, and the share of net profit linked to these activities should account for at least $50 \%$ of the total net profit reported by the enterprise.

The first three criteria are all related to socially vulnerable groups-qua workers, producers and consumers, respectively. The "Amendments to the Law on the Development of Small and Medium Enterprises" do not only provide important definitions; they also determine the framework for possible SE business models. Theoretically, a social entrepreneur creates value in favour of a beneficiary who is the enterprise's main stakeholder. Business models could be defined depending on the position of the beneficiary in the value chain: (1) at the beginning of the value chain; (2) inside the value chain; or (3) at the end of the value chain (Aray 2014). Obviously, the first three criteria are directly correlated with these business models. The fourth criterion is associated with a type of activity that goes beyond supporting well-defined vulnerable groups, but which, in the opinion of the state, has significant social value. Such activities include, among others, the provision of psychological, pedagogical and other services aimed at strengthening the family; the organisation of recreation and rehabilitation services for children; the provision of services in the field of preschool, general and additional education of children; psychological, pedagogical, medical and social assistance to schoolchildren; training activities for workers and volunteers of socially oriented non-profit organisations; cultural and educational activities. 
Enterprises that meet one of these criteria acquire the status of social enterprise and are recorded in the corresponding list in the Unified Register of SMEs. Federal and regional governments can provide such enterprises with financial, infrastructural, property, information, consulting, educational and other support. The list of social enterprises is subject to annual review and, accordingly, the status of social enterprise only reflects the current characteristics of a SME. According to the Agency for Social Initiatives, by the end of 2019, about 70,000 Russian SMEs potentially met the requirements to be considered as social enterprises and could thus qualify for inclusion in the list of social enterprises (Lavrova 2019).

\subsection{Large Corporations}

Leading Russian corporations, such as Severstal, RUSAL, LUKOIL, SUEK, Metalloinvest and Norilsk Nickel have, since the beginning of the 2010s, started to reorient their participation in solving social problems towards support to social entrepreneurship. The aforementioned "social contract" between the state and large enterprises is not being violated; rather, it is developing towards more rational business choices. Corporations consider support for social entrepreneurship-such as training, consulting, mentoring, project support and grants-as an effective, responsible form of innovation, partly replacing traditional corporate giving and acts of private charity by corporations' largest shareholders. It is significant, in this regard, that the leading non-governmental centre for social entrepreneurship development in Russia is the Fund of Regional Social Programmes "Our Future", 7 a family charity foundation created by Vagit Alekperov, who is the president and a leading shareholder of LUKOIL. This fund identifies, trains and supports (through loans and grants) social entrepreneurs. By the beginning of 2020, the "Our Future" Fund had provided, since its creation in 2007, interest-free loan support to 255 social entrepreneurial projects from 58 regions of the Russian Federation. The definition of social entrepreneurship most commonly used in the country until the adoption of the aforementioned amendments, in July 2019, was also the one adopted by the "Our Future" Fund: "Social entrepreneurship is an entrepreneurial activity aimed at mitigating or solving social problems, which is characterised by the following major features: social impact, innovation, self-sufficiency and financial stability, scalability and replicability, entrepreneurial approach" (Zvereva 2015).

Corporations put special emphasis on targeted support to social entrepreneurship in the territories where they are present, focusing on the social problems of the local communities. Besides, as a rule, corporations actively cooperate with regional administrations. For example, in 1999, Severstal created the "Urban Development Agency" for the development of SMEs in collaboration with the City Council of Cherepovets, 
the location of its largest steel plant. In 2013, this "Urban Development Agency" launched a programme of support for social entrepreneurs. ${ }^{8}$ During its first year of existence, the Agency identified social problems in the city, set up the "Bank of Social-Business Ideas", consulted 850 social entrepreneurs, provided financial support to seventeen enterprises and property support to six others, developed cooperation with the "Our Future" and "Reach for Change" Funds, and established the CISS of the Vologda region. Another example is that of RUSAL, which, in 2013, created a network of CISSs in six cities on the territory where it is present; this network focuses on the centralisation of government and business efforts. By the beginning of 2020, there were 2,853 social entrepreneurs, implementing 142 social-business projects, trained in RUSAL's network of CISSs; the total volume of corporate investment in the development of social entrepreneurship accounted for more than RUB20 million (about $€ 280,000$ ), and the network partnered with more than 50 organisations, including economic departments of city and regional administrations, centres for the development of and support to entrepreneurship, the Union of Industrialists and Entrepreneurs, Chambers of Commerce, SBERBANK offices and urban centres of employment. ${ }^{9}$

\section{Typology of Social Entrepreneurship in Modern Russia}

The most important feature of social entrepreneurship in the Russian Federation is the "semi-official" nature of its development. On the one hand, since July 26, 2019, as already underlined, social entrepreneurship has had a specific legal status, that is, it does exist de jure. On the other hand, de facto social entrepreneurship is developing as a specific type of activity supported by the state and corporations. Actual "social enterprises" are not only the SMEs (both individual entrepreneurs and commercial organisations) meeting the requirements defined in the aforementioned Amendments of July 2019, but also NPOs which are not covered by this particular piece of legislation but correspond to the concept of social enterprise, such as it is generally understood at the international level.

Observation of actual practices dispels stereotypes existing among the general public in Russia, according to which NPOs could not be engaged in business activities. ${ }^{10}$ However, NPOs' business activities are possible only insofar as they serve the purposes for which the NPO was created. Among these activities, a distinction is made between "pure" entrepreneurship, without any social objective and simply aimed at ensuring the financial sustainability of the NPO, and social entrepreneurship, which pursues a social objective in itself. Moreover, the law specifically identifies "socially oriented non-profit organisations" (SONPOs) (Art. 2, $\$ 2.1$ ), which carry out activities aimed at solving social problems and developing civil society in the Russian Federation. The same law provides 


\section{Blagov \& Aray}

for financial, property, information, consulting and educational support for SONPOs by state authorities and local self-government.

Social entrepreneurship in the Russian Federation is focused on creating shared value. It addresses the way of conducting operations, with a view to increasing the company's competitiveness while improving economic and social conditions in the communities in which it operates. Moreover, "real social entrepreneurship should be measured by its ability to create shared value, not just social benefit" (Porter and Kramer 2011). Accordingly, the most important criterion of social entrepreneurship de facto becomes not simply the pursuit of a social mission but of a socioentrepreneurial one (to which we will refer, in the following, as to an "SE mission"). This mission aims to form a kind of system that enables the creation of shared value in a sustainable way, solving - or at least participating in solving — a specific social problem. Obviously, the "vision" of the social entrepreneur, in this case, should reflect the ideal picture of mitigating or solving a particular social problem. At first glance, it might appear to contradict the important conclusion that "for all schools of thought, the explicit aim to benefit the community or the creation of social value is the core mission of social entrepreneurship and social enterprise" (Defourny and Nyssens 2010). Nevertheless, being based on the changing "semi-official" nature of SE development, this contradiction is more a dialectic one than a formal one.

On the other hand, all the legal forms that are available to de facto social enterprises-individual enterprises and commercial organisations as well as NPOs-have their own advantages and disadvantages for the development of social entrepreneurship. The choice of a legal form is important for both existing entrepreneurs and start-ups. The following typology of de facto social-entrepreneurship models in the Russian Federation can be proposed:

- individual enterprises operating on the basis of the SE missionIE-SE model;

- commercial organisations operating on the basis of the SE missionCO-SE model;

- NPOs/SONPOs implementing certain SE-mission-driven project(s)_ NPO-SE model (Blagov and Aray 2019).

The analysis of the way in which 140 graduates from the Executive Education Programme "Project Development for Social Entrepreneurs" (conducted at the St. Petersburg University Graduate School of Management in 2012-2015) implemented their business plans provides some indications about the comparative popularity of each of these three models (Blagov and Aray 2019). The first model (IE-SE model) was used by 15 respondents (10.7\%); the second model (CO-SE model), by 36 respondents $(25.7 \%)$; and the third model (NPO-SE model), by 
86 respondents $(61.5 \%)$. Three social entrepreneurs $(2.1 \%)$ used more than one model simultaneously. These data are closely connected to the personal history of the graduates' entrepreneurial activities: the third model was used only by pre-existing NPOs; the first model was mainly used by business start-ups; and the second model was used both by existing NPOs and by individual entrepreneurs for obtaining additional opportunities for growth.

In the following paragraphs, typical examples of these three models are presented (Blagov and Aray 2019).

\subsection{IE-SE Model: The Example of the Individual Enterprise A. V. Tikhomirova}

The Children's Book Bus "Bumper"11 project was created by the individual enterprise A.V. Tikhomirova in response to an acute social problem in Russian society-a sharp drop in interest in reading among children and adolescents. This problem is particularly clearly felt in remote areas, where there are no well-stocked libraries, and modern bookstores cannot be opened due to low profitability. The Book Bus visits remote villages and towns, delivers free master classes, organises literary meetings, offers psychological training for children and adults, and sells carefully selected children's literature. The main source of income is the beneficiaries themselves, who are willing to pay for the goods in exchange for the services provided.

As many other organisations using this model, Bumper integrates donations into its core activities. For example, a buyer can purchase a book in Bumper for charitable purposes; the acquired book is then given to consumers who cannot afford to buy it themselves. Volunteering, as a rule, is non-systemic but rather appears under the form of spontaneous initiatives by consumers and other stakeholders. Many events are held at the initiative of children and their parents, who are loyal customers of the organisation, or with their participation or financial support.

\subsection{CO-SE Model: The Example of "Liberty" LLC}

The travel company for wheelchair users "Liberty" LLC ${ }^{12}$ has been working in the areas of both domestic and international tourism, providing specialised "invatours" (i.e. tours for disabled persons) for foreigners in St. Petersburg and Moscow, as well as specialised "invatours" for Russians abroad and throughout Russia. The financial stability of the project is secured through the provision of travel services to foreign tourists with disabilities at world-market prices. Revenue from this service not only allows to cover the costs of the project but also serves to provide services to Russian people with disabilities at prices commensurate with the level of costs but below the market price. 
This model allows the enterprise to more effectively attract both nonrepayable funds for specific purposes (grants and donations) and repayable funds from loans. For example, in 2010, Liberty LLC received interest-free loans for a period of four years from the "Our Future" Fund. By contrast, voluntary work is not widely used, mainly due to the high level of specificity of services for wheelchair users, which requires specialised training.

\subsection{NPO-SE Model: The Example of "Safe Home" CF}

The "Safe Home" Charity Foundation (CF) ${ }^{13}$ was established in 2009. The Foundation implements programmes in the field of provision of comprehensive care for people of any age and sex who find themselves in difficult situations, who are victims of human trafficking or who are faced with various forms of violence.

"Safe Home" CF attracts donations from individuals and legal entities, receives grants and conducts fundraising activities. "Safe Home" CF also systematically attracts volunteers, who represent a significant part of the organisation's workforce. In addition, the Foundation earns income from its social entrepreneurship activities: "Jewellery Girls" is a project of art therapy for children, adolescents and young adults (from 5 to 24 years old) faced with the problem of human trafficking or who are at risk in this regard; jewellery made in the classroom is sold through various promotional channels by the organisation, and most of the project's expenditure is covered by income from jewellery sales. In fact, the "Jewellery Girls" project implements its own SE mission within the general "social" mission of "Safe Home" CF, ensuring the development of a sustainable system focused on shared value creation.

Obviously, in accordance with the "Amendments to the Law on the Development of Small and Medium Enterprises", only the first two models can claim the status of social enterprise de jure. Socially entrepreneurial projects of NPOs corresponding to the third model can apply for this status when they create a separate commercial entity—an individual enterprise or commercial organisation-for the implementation of this project. However, many social entrepreneurs began to combine all three models long before the adoption of the amendments to the law; this allows them to find a balance in an immature institutional context, to get access to different resources and to receive support from heterogeneous stakeholders.

\section{Conclusion}

The development of social entrepreneurship in modern Russia is a very complex and controversial process. The state is currently playing the role of the main driver of social-entrepreneurship development, in cooperation with leading corporations. As a result, social entrepreneurship in 
modern Russia is developing in a "semi-official" way. On the one hand, social enterprises exist de jure as a particular kind of SMEs. The status of social enterprise is temporary and is granted on an annual basis, and the right to related support is conditional on strict compliance with certain criteria of activity. On the other hand, the "socio-entrepreneurial" mission can be pursued de facto by organisations operating under different organisational/legal forms, as individual enterprises, commercial organisations or NPOs involved in particular socio-entrepreneurial projects.

Despite support from the state and leading corporations, the level of socially entrepreneurial activity in Russia remains quite low, with only an estimated $1.2 \%$ of the adult population involved in social enterprises (Khaleeva 2014). There are several reasons for this.

First of all, the Russian Federation is characterised by a low level of entrepreneurial activity in general. According to the 2017 Global Entrepreneurial Monitor report, which examined the situation in 65 countries, Russia was ranked last in terms of level of entrepreneurial intentions (GEM 2017). The slow development of entrepreneurship is embedded, in turn, in underdeveloped civil-society institutions.

In addition, the driving role of the state and corporations, with their particular goals and approaches, creates certain limitations to socialentrepreneurship development. Some important social problemslike alcoholism, drug addiction, corruption and bureaucracy-are not included in the officially acknowledged list of social problems, which hinders the development of social entrepreneurial initiatives in these areas. Also, being directly connected to relatively strong financial support, the social-entrepreneurship "movement" can attract more moneyseekers, "experts" and related bureaucrats than socially responsible entrepreneurs.

Finally, the whole Russian socio-economic system, including social entrepreneurship, is still going through a transition. It takes time for the "Amendments to the Law on the Development of Small and Medium Enterprises", which govern social entrepreneurship, to actually take effect-not only in providing targeted support to specific social enterprises but also in contributing to the consolidated development of the entire ecosystem of social entrepreneurship in Russia.

\section{Notes}

1. Kievan Rus' was a loose federation of East Slavic tribes that existed in Europe from the late 9th to the mid-13th century. The modern nations of Russia, Ukraine and Belarus all claim Kievan Rus' as their cultural ancestors.

2. See http://dom-noi.ru/.

3. This annual catalogue contains a brief description of each of the most famous social enterprises in Russia.

4. Orders of the Ministry for Economic Development No. 223 of 23.04.2012, Art.5.19; No. 167 of 25.03.2015, Art.7.4. 


\section{Blagov \& Aray}

5. Regulation of the Government of the Russian Federation No. 1083-p of 2.06.2016, p. 11.

6. Federal Law No. 245-FZ of 26.07.2019.

7. See www.nb-fund.ru.

8. See www.agr-city.ru.

9. See https://fcsp.ru/program/business_people/.

10. Federal Law dd. 12.01.1996 of No. 7-FZ “On Non-Profit Organisations", Ch. I, Art. 24, $\$ 2$.

11. See www.bumperbooks.ru.

12. See http://accessiblerussia.com/.

13. See www.safehouse.rawdelicious.se/ru.

\section{References}

Aray, Y. (2014) "Social Entrepreneurship: Basic Business Models”, E-book of The International Conference "GSOM Emerging Markets Conference: Business and Government Perspectives”, GSOM SPbU, October 16-17.

Aray, Y. \& Burmistrova, T. (2014) "Spetsifika bisnes-modeley v sotsialnom predprinimatelstve", Russian Management Journal, Vol. 12, No. 4, pp. 55-78.

Batalina, M., Moskovskaya, A. \& Taradina, L. (2008) “Obsor opita i kontseptsiy sotsialnogo predprinimatelstva s uchetom vozmozhnostey ego priminenija $\mathrm{v}$ sovremennoy Rossii”, Working Paper, No. 1/2008/02, Moskow: NRU HSE.

Blagov, Y. (eds) (2017) Upravleniye projectami $v$ oblasti sotsialnogo predprinimatelstva, Saint Petersburg: Izdatelstvo Sankt-Peterburgskogo universiteta.

Blagov, Y. \& Aray, Y. (2010) "Sotsialnoye predprinimatelstvo: problemi tipologii”, Vestnik Sankt-Peterburgskogo universiteta. Seriia Menedzhment, Vol. 3, pp. 109-14.

Blagov, Y. \& Aray, Y. (2019) “The emergence of social entrepreneurship in Russia”, Social Enterprise Journal, Vol. 15, No. 2, pp. 158-78.

Blagov, Y. \& Petrova-Savchenko, A. (2012) "Corporate philanthropy in Russia: Evidence from a national awards competition", Corporate Governance: The International Journal of Business in Society, Vol. 12, No. 4, pp. 534-47.

Defourny, J. \& Nyssens, M. (2010) “Conceptions of social enterprise and social entrepreneurship in Europe and the United States: Convergences and divergences", Journal of Social Entrepreneurship, Vol. 1, No. 1, pp. 32-53.

Elyutin, O. (2003) “Kooperatsija v Rossii: nevostrebovanniy opit”, Nauka $i$ Zhizn, Vol. 5. Available HTTP: www.nkj.ru/archive/articles/2887/.

Gatilova, L. (2008) “Organizatsija i deyatelnost domov trudolyubija v guberniyah Tsentralnogo Chernozemja v kontse XIX-nachale XX v.: po materialam Kurskoy i Tambovskoy guberniy", Vestnik Tambovskogo universiteta. Seriia: Gumanitarniye nauki, Vol. 7, pp. 343-50.

GEM (2017) Global Entrepreneurship Monitor 2016/2017, Global Entrepreneurship Research Association.

Kazakova-Apkarimova, E. (2010) "Istoricheskiy opit sotsialnogo predprinimatelstva na Urale", Isvestiya UrGEU, Vol. 6, No. 32, pp. 130-4.

Kerlin, J. (2009) "A comparison of social enterprise models and context", in Kerlin, J. (ed) Social Enterprise: A Global Comparison, Lebanon, NH: Tufts University Press, pp. 184-200. 
Kerlin, J. (2013) "Defining social enterprise across different contexts: A conceptual framework based on institutional factors", Nonprofit and Voluntary Sector Quarterly, Vol. 42, No. 1, pp. 84-108.

Kerlin, J. (2017) “The macro-institutional social enterprise framework: Introduction and theoretical underpinnings: Understanding institutional context and influence", in Kerlin, J. (ed) Shaping Social Enterprise: Understanding Institutional Context and Influence, London: Emerald Publishing, pp. 1-26.

Khaleeva, J. (2014) The State of Social Entrepreneurship in Russia, SEFORIS Country Report.

Lavrova, I. (2019) "Vigoda i obschestvo: kak rasvivaetsa sotsialnoye predprinimatelstvo", RBK Plus. Available HTTP: https://plus.rbc.ru/news/5dc192557a 8 aa936c82d2fed.

Moskovskaya, A. (ed) (2011) Sotsialnoye predprinimatelstvo $v$ Rossii i v mire: practica $i$ issledovanija, Moskow: Izdatelskiy Dom VSE.

Moskovskaya, A. \& Soboleva, I. (2016) "Social entrepreneurship in the system of social policy: International experience and prospects of Russia", Studies on Russian Economic Development, Vol. 27, No. 6, pp. 683-8.

Porter, M. \& Kramer, M. (2011) "The big idea: Creating shared value", Harvard Business Review, Vol. 89, No. 1/2, pp. 62-72.

Utkin, A. (2014) "Istorija blagotvoritelnosti v Rossii: tsarskoy, sovetskoy i sovremennoy”, RIA Novosti. Available HTTP: https://ria.ru/disabled_know/ 20130226/924715394.html.

Vayner, V. \& Bolshakova, D. (2015) Sotsialnoye predprinimatelstvo $v$ Rossii, Moskow: Wowhouse.

Vayner, V., Bolshakova, D. \& Gulbekyan, M. (2016) Sotsialnoye predprinimatelstvo $v$ Rossii, Moskow: Wowhouse.

Vayner, V., Bolshakova, D. \& Gulbekyan, M. (2017) Sotsialnoye predprinimatelstvo $v$ Rossii, Moskow: Wowhouse.

Vetrova, E. (2015) "Sotsialnoye predprinimatelstvo kak factor sotsialno-econom icheskogo razvitiya obschestva", Vestnik Tambovskogo universiteta. Seriia: Gumanitarniye nauki, Vol. 1, pp. 20-4.

Zelenova, E. (2010) "Sotsialnoye predprinimatelstvo-novaya forma blagotvoritelnoy deyatelnosti”, Sotsialnaya politika i sotsialnoye partnerstvo, Vol. 9 , pp. 64-73.

Zvereva, N. (2015) Sozdanije uspeshnogo sotsialnogo predprijatija, Moskow: Alpina Publishers. 